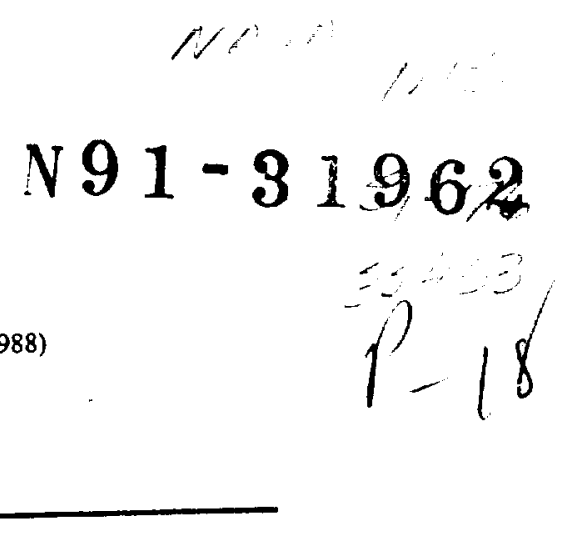

C. H. DRUmmond III AND W. E. LeE

The Ohio State University

Columbus, $\mathrm{OH}$

\author{
W. A. SANDers AND J. D. Kiser \\ NASA Lewis Research Center \\ Cleveland, $\mathrm{OH}$
}

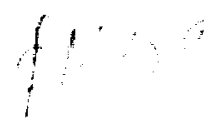

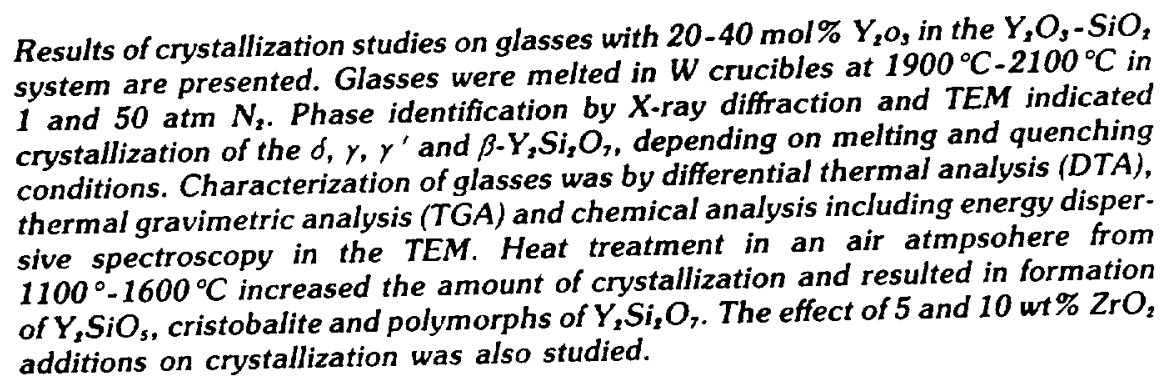

\title{
Introduction
}

The use of high-temperature materials in applications such as gas turbine engines requires that the material not only be able to withstand the high temperatures, but also maintain acceptable mechanical properties during use at these temperatures, but also maintain acceptable nechamical properties during use at these temperatures or in cycling to these temperatures. Silicon nitride continues to receive extensive study as one possible material. We report here results on the crystallization of bulk glasses similar in composition to those found in the intergranular glassy grain boundary phases of sintered silicon nitride with yttria as the sintering aid. The silicon nitride composition studied contained a $6 \%$ by weight addition of $\mathrm{Y}_{2} \mathrm{O}_{3}$ to the starting silicon nitride powder as processed by NASA Lewis.' This composition lies in the $\mathrm{Si}_{3} \mathrm{~N}_{4}-\mathrm{Y}_{2} \mathrm{Si}_{2} \mathrm{O},-\mathrm{Si}_{2} \mathrm{~N}_{2} \mathrm{O}$ triangle of the phase diagram² in Fig. 1. Since this powder contains silica present as a thin layer on each $\mathrm{Si}_{3} \mathrm{~N}_{4}$ grain plus that resulting from addition to the starting powders or from possible oxidation during grinding, the exact composition of the intergranular glassy phase is difficult to determine.

Improvement in the high-temperature mechanical properties may result upon crystallization of a higher-melting-point crystalline phase from the glassy grain boundary phase. Crystallization of the glassy phase may be facilitated by the addition of a nucleating agent or by the alteration of the composition.

\section{Review of $\mathrm{Y}_{2} \mathrm{O}_{3}-\mathrm{SiO}_{2}$ Crystalline Phases}

The diffraction data on $\mathrm{Y}_{2} \mathrm{Si}_{2} \mathrm{O}_{7}$ crystalline polymorphs have been summarized by Liddel and Thompson. ${ }^{3} \mathrm{~A}$ review of the available data and some 
of their own indicated that there are four polymorphs: $\alpha, \beta, \gamma$, and $\delta$. The low temperature polymorph, $\alpha$, transforms to $\beta$ as the temperature is increased. Figure 2 gives the temperature of the transformations and the densities of the various polymorphs of $\mathrm{Y}_{2} \mathrm{Si}_{2} \mathrm{O}_{2}$. The structure of all polymorphs consists of $\mathrm{Si}_{2} \mathrm{O}_{7}{ }^{6-}$ units. The $\mathrm{X}$-ray powder diffraction file indicates that there are two different patterns of the $\gamma$ phase, which are designated $\gamma$ (JCPDS: $20-1416)$ and $\gamma^{\prime}(32-1448)$ in this paper. There are several polymorphs of the $\mathrm{Y}_{2} \mathrm{Si}_{2} \mathrm{O}$, phase as discussed by Liddel and Thompson. ${ }^{3}$ The existence of the $2 \mathrm{Y}_{2} \mathrm{O}_{3} 3 \mathrm{SiO}_{2}$ phase as shown in the published phase diagram ${ }^{4}$ has not been confirmed, and, in fact, the existence of such a phase has been questioned. ${ }^{3}$ The volume change associated with the polymorphic inversions of $\mathrm{Y}_{2} \mathrm{Si}_{2} \mathrm{O}$, is as large as $6.7 \%$ and may be significant in the crystallization of intergranular glassy grain boundary phases in silicon nitride (see these proceedings). 'The density of these glasses has not been reported.

\section{Experimental Procedure}

Reagent grade silica and yttrium oxide were ball milled for four hours with HSPN grinding media in dry alcohol and dried. The powder was dry milled for two hours then pressed into pellets and placed in tungsten crucibles for melting in a high-pressure nitrogen furnace. ${ }^{6}$ Powders were melted from $1900^{\circ}$ to $2100^{\circ} \mathrm{C}$, depending on the composition, and were held for four hours under $50 \mathrm{~atm}$ nitrogen. Additional melts were also made in $1 \mathrm{~atm}$ nitrogen. No difference in properties or crystallization behavior was observed between these two melting conditions. In some cases repeated melts were made in the same crucible by the addition of more pellets. In general, this procedure of repeated melts in the same crucible is not recommended because the crucible sometimes cracked and physical and chemical alteration of the melt was observed, perhaps because of the initiation of reactions which resulted in the deposition of tungsten or volatilization of silica from the melt. It was necessary to break the crucibles to remove the melt. The as-melted samples were X-rayed to identify crystalline phases formed on cooling. Additional heat treatments on as-melted material were carried out in air from $1100^{\circ}-1600^{\circ} \mathrm{C}$ and followed by phase identification using X-ray diffraction and TEM (transmission electron microscopy).

The compositions melted ranged from $20-40 \mathrm{~mol} \% \mathrm{Y}_{2} \mathrm{O}_{3}$. This compositional range is centered around the lower temperature eutectic region shown in Fig. 3, which is a modified version of the $\mathrm{Y}_{2} \mathrm{O}_{3}-\mathrm{SiO}_{2}$ phase diagram without inclusion of the $\mathrm{Y} 2 \mathrm{~S} 3$ phase. This range covers compositions observed in the intergranular glassy grain boundary phase in as-processed NASA Lewis silicon nitride, assuming the absence of nitrogen within the glass. The exact chemical analysis of this phase is difficult to determine because the EDS (energy dispersive spectroscopy) system on the TEM at NASA Lewis has a Be window, which precludes soft $\mathrm{X}$-rays such as those that arize from $\mathrm{O}$ or $\mathrm{N}$. In earlier studies on these materials, ${ }^{1}$ no crystallization of nitrided crystalline phases was observed. This may have been due to incomplete crystallization for the given heat treatment of the material or to the inherent difficulties of crystallizing small amounts of glassy material. ${ }^{7}$

The primary glass composition studied was designated GSI. This is the eutectic composition between $\mathrm{SiO}_{2}$ and $\mathrm{Y}_{2} \mathrm{Si}_{2} \mathrm{O}$, and is similar to the intergranular glassy grain boundary composition without nitrogen in the asprocessed $6 \mathrm{Y}$ silicon nitride. The formulation and as-melted composition is 
given in Table $\mathrm{I}$. The presence of tungsten will be discussed in the results section. Less than $0.2 \%$ nitrogen was found, indicating that little nitrogen was dissolved in the melt as a result of the $50 \mathrm{~atm}$ nitrogen overpressure. In addition, a GSII composition was melted containing $52 \mathrm{wt} \% \mathrm{Y}_{2} \mathrm{O}_{3}$ and $48 \% \mathrm{SiO}_{2}$ and $\mathrm{a} \mathrm{Y}_{2} \mathrm{Si}_{2} \mathrm{O}$, composition. The GSZ5 and GSZ10 compositions are the same as GSI with 5 and $10 \mathrm{wt} \% \mathrm{ZrO}_{2}$ added as a nucleating agent. A $2 \mathrm{Y}_{2} \mathrm{O}_{3} \cdot 3 \mathrm{SiO}_{2}$, (Y2S3), composition was also melted to determine the stability of this crystalline phase.

\section{Results}

In all cases X-ray diffraction of the as-quenched melt indicated partially crystlalization. The diffraction pattern from the as-melted GSI is shown in Fig. 4. The melt is amorphous but with a considerable amount of $\delta-\mathrm{Y}_{2} \mathrm{Si}_{2} \mathrm{O}$, phase present. Even in the case of sol-gel derived glasses at lower temperatures, partial crystallization was observed. Most of the melts contained the $\delta$ phase, as would be expected from a rapid quench of the melts. However, in some cases the $\gamma$ and $\beta$ phases were observed. A satisfactory explanation cannot be given. The quench obtained in these melts was not a rapid one-estimated to be $270 \% \mathrm{~min}$. The furnace did not permit the more rapid quench that might have been obtained, for example, by pouring into a liquid. Exactly what melting and quenching conditions would result in the formation of the lower temperature polymorphs is not known. In some cases reheating of the melt might contribute to the existence of lower temperature polymorphs at higher temperatures, or the presence of tungsten in the melts may serve as a nucleating agent.

The GSII composition was phase separated on melting, which is expected from the phase diagram. The only exception to the partial crystallinity of the as-melted material was the $\mathrm{Y} 2 \mathrm{~S} 3$ composition which $\mathrm{X}$-rayed amorphous (Fig. 5). Further experiments are being carried out to confirm this result. The GSZ5 and GSZ10 compositions consisted of $\beta-$ and $\gamma-Y_{2} \mathrm{Si}_{2} \mathrm{O}$, respectively together with cubic $\mathrm{ZrO}_{2}$.

The as-melted GSI composition produced $\beta-, \gamma-$, and $\delta-\mathrm{Y}_{2} \mathrm{SI}_{2} \mathrm{O}_{7}$ for different melts. Results of heat treatment of these melts are shown in Fig. 6. The $\mathrm{X}$-ray diffraction pattern for a heat treatment of $24 \mathrm{~h}$ at $1300^{\circ} \mathrm{C}$ is given in Fig. 7. In this case it would appear that all of the $\delta$ phase did not transform. In Fig. 8, a TEM micrograph of the GSI composition heat treated for $4 \mathrm{~h}$ at $1600^{\circ} \mathrm{C}$ shows the presence of $\mathrm{SiO}_{2}$ glass and $\delta-\mathrm{Y}_{2} \mathrm{Si}_{2} \mathrm{O}_{1}$, as expected from the phase diagram. The temperature range of these heat treatments was $1100^{\circ}-1600^{\circ} \mathrm{C}$, and times ranged from the initial melt to $43 \mathrm{~h}$. In general, the expected phases were formed, but in some cases metastable phases existed for long periods of time at a given temperature. Cristobalite was not present in sufficient amounts to be observed by X-ray diffraction but was identified by TEM. There was some evidence that the initial crystalline phases formed from the as-quenched melt may have determined the subsequent crystal phases formed. Further work needs to be done to clarify these results.

The results of heat treatment of the GSZ compositions containing 5 and 10 wt $\% \mathrm{ZrO}_{2}$ are shown in Fig. 9. For the GSZ5 composition $\beta-\mathrm{Y}_{2} \mathrm{Si}_{2} \mathrm{O}_{7}$ was always observed with the cubic $\mathrm{ZrO}_{2}$. In GSZ10 various phases crystallized including the $y$ and $\delta$ phases. The YS2 and Y2S3 results are shown in Fig. 10. Crystallization of $Y_{2} \mathrm{SiO}_{3}$ and $\delta-Y_{2} \mathrm{Si}_{2} Y_{7}$ at $1600^{\circ} \mathrm{C}$ are the phases expected from the phase diagram with no formation of crystalline $2 \mathrm{Y}_{2} \mathrm{O}_{3} 3 \mathrm{SiO}_{2}$ as shown 
in the diffraction pattern in Fig. 11. Crystallization of a polymorph at temperatures above its conversion temperature is unexplained. It may have been due to formation of crystal nuclei on cooling from the melt and subsequent growth during heat treatment. Further crystallization studies are underway to better define the range of temperature stability of these polymorphs.

One of the more troublesome asepcts of this investigation was the presence of tungsten in the melts. Obtaining a satisfactory crucible material was difficult. Materials tried included $\mathrm{Pt}, \mathrm{Rh}, \mathrm{Ir}$ and various alloys of these elements, $\mathrm{BN}, \mathrm{SiC}$, and $\mathrm{Si}_{3} \mathrm{~N}_{4}$. None of these materials resulted in melts without dissolution and chemical alteration of the melt or the crucible material. Chemical analysis indicated that tungsten concentrations in the range $0.10-0.80$ wt $\%$ were dissolved or precipitated in the melts. In some cases, tungsten was deposited on the sides of the crucible or on the melt surface. It is not clear how this formed, but a possible mechamism is oxidation of tungsten to form a vapor which then deposited and decomposed to tungsten. Since little oxidation of tungsten used as shields in the furnace was observed, the concentration of oxygen in the furnace must have been very low. At these temperatures the vapor pressure of tungsten is too low to account for vapor transport of the tungsten metal. It is also possible that tungsten may have dissolved in the melts when liquid.

The TGA scan shown in Fig. 12 for a GSZ5 composition to $1800^{\circ} \mathrm{C}$ indicates a $40 \%$ weight loss, most likely due to the volatilization of SiO. Melting was indicated at $1750^{\circ} \mathrm{C}$ and a crystallization on cooling at $1450^{\circ} \mathrm{C}$. No crystallization or polymorphic inversions were observed on heating nor was there any indication of a glass transition. On cooling again, no polymorphic inversions were observed. Further studies are in progress to see if any crystallization can be detected by heat treatment during a DTA scan or in isothermal holds. DTA results on the GSZ compositions indicated possible crystallization on heating, but these results need to be examined further. It may be of interest to investigate other nucleating agents; however, most would lower the refractoriness of the glassy phase, which would be undesirable in the processing of silicon nitride.

\section{Conclusions}

Results of crystallization studies in the $\mathrm{Y}_{2} \mathrm{O}_{3}-\mathrm{SiO}_{2}$ system have shown that, in general, the expected crystalline phases form when heat treated. It was also found that transformations were sluggish and in some cases phases could exist metastably. When the crystallization studies on the bulk glasses have been completed, the heat-treatment schedules which optimize crystallization will be applied to the $6 \mathrm{Y}$ silicon nitride composition to attempt to improve the hightemperature mechanical properties.

\section{Acknowledgement}

Research at The Ohio State University was supported on NASA Grant No. NAG 3-824.

\section{References}

'W. A. Sanders and D. M. Mieskowski, "Strength and Microstructure of Sintered Si,N, with Rare-Earth-Oxide Additions," J. Am. Ceram. Soc., 64 [2] 304-309 (1985).

"L J. Gauckler, H. Hohnke, and T. Y. Tien, "The System $\mathrm{Si}_{3} \mathrm{~N}_{4}-\mathrm{SiO}_{2}-\mathrm{Y}_{2} \mathrm{O}_{3}, " \mathrm{~J}$. Am. Ceram. Soc., $63[1-2] 35-37$ (1980).

"K. Liddeli and D. F. Thompson, "X-ray Diffraction Data for Yttrium Silicates," J. Br. Ceram. Trans., 85 17-22 (1986). 
'E. M. Levin, C. R. Robbins, and H. F. McMurdie, Phase Diagrams for Ceramists 1969 Supplement, The American Ceramic Society, Inc., Columbus, OH; Fig. 2388.

${ }^{\prime}$ W. E. Lee, C. H. Drummond III, G. E. Hilmas, J. D. Kiser, and W. A. Sanders, "Microstructural Evolution on Crystallizing the Glassy Phase in a 6 Weight $\% \mathrm{Y}_{2} \mathrm{O}_{3}-\mathrm{Si}_{3} \mathrm{~N}_{4}$ Ceramic," these proceedings.

"W. A. Sanders and T. P. Herbill, "Characteristics of $\mathrm{Si}_{3} \mathrm{~N}_{1}-\mathrm{SiO}_{2}-\mathrm{Ce}_{2} \mathrm{O}$, Compositions Sintered in High-Pressure Nitrogen," J. Am. Ceram. Soc., 66 [12] 835-41 (1983).

'R Raj and F. F. Lange, "Crystallization of Glass (or a Liquid) Segregated in Grain Boundaries," Acta Met., 201 1993-2000 (1981) and R. Raj, "Morphology and Stability of the Glass Phase in Glass-Ceramic Systems," J. Am. Ceram. Soc., 64 [5] 245-48 (1981).

Table I. Chemical Analysis of GSI

\begin{tabular}{lcr}
\hline & $\begin{array}{c}\text { As Formulated } \\
(w t \%)\end{array}$ & As Melted \\
\hline $\mathrm{SiO}_{2}$ & 40.6 & 39.94 \\
$\mathrm{Y}_{2} \mathrm{O}_{3}$ & 59.4 & 60.96 \\
$\mathrm{WO}_{3}$ & & 0.92 \\
$\mathrm{~N}$ & & 0.12 \\
& & $\frac{101.94}{109}$ \\
\hline
\end{tabular}

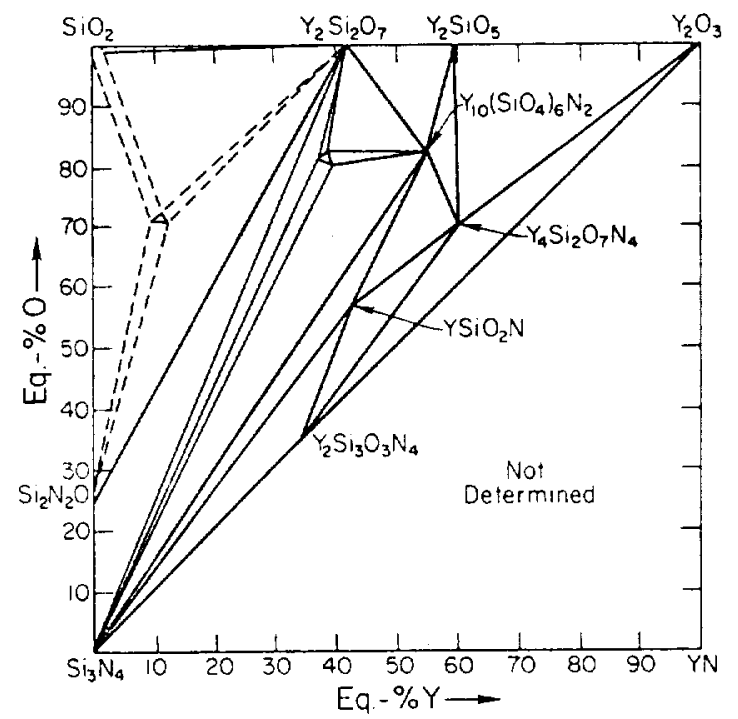

Fig. 1. Isothermal section of the system $\mathrm{Si}_{3} \mathrm{~N}_{4}-\mathrm{SiO}_{2}-\mathrm{Y}_{2} \mathrm{O}_{3}$ at $1500^{\circ}$. 


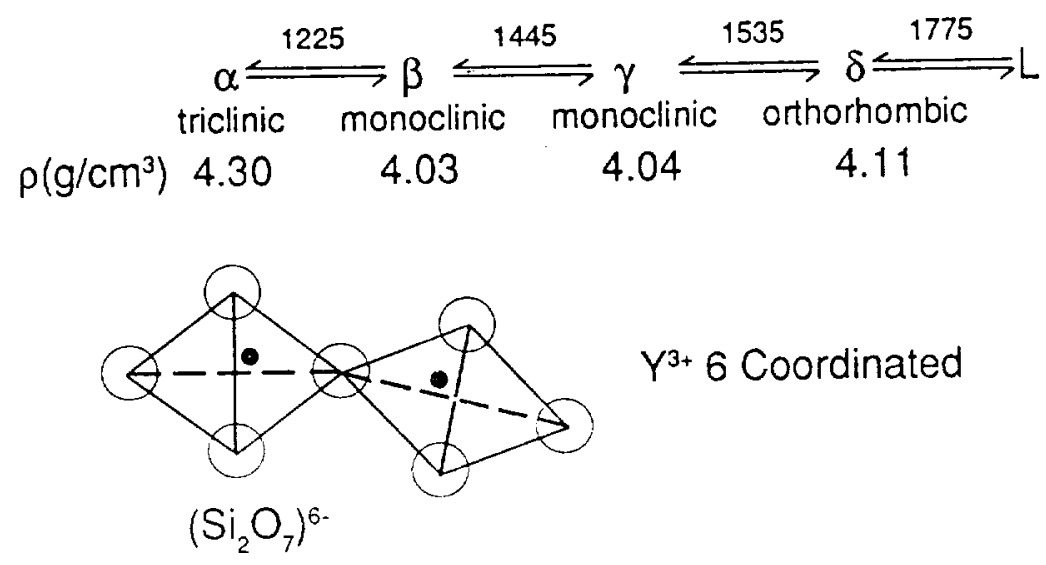

Fig. 2. Polymorphs of $\mathrm{Y}_{2} \mathrm{Si}_{2} \mathrm{O}_{7}$.

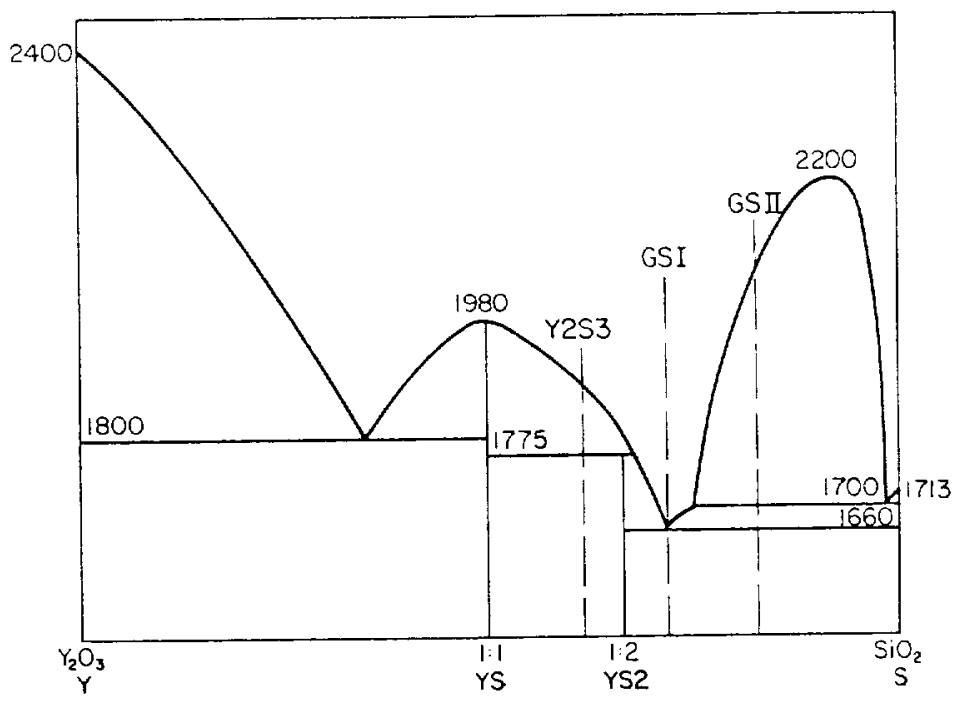

Fig. 3. $\mathrm{Y}_{2} \mathrm{O}_{3}-\mathrm{SiO}_{2}$ phase diagram. 

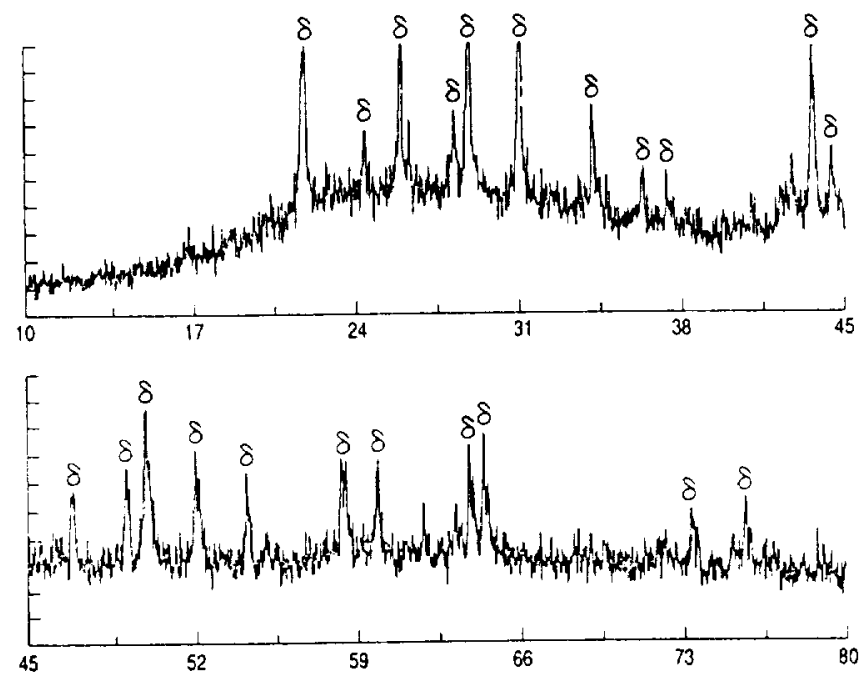

Fig. 4. X-ray pattern of as-melted GSI with $\delta-\mathrm{Y}_{2} \mathrm{Si}_{2} \mathrm{O}$,
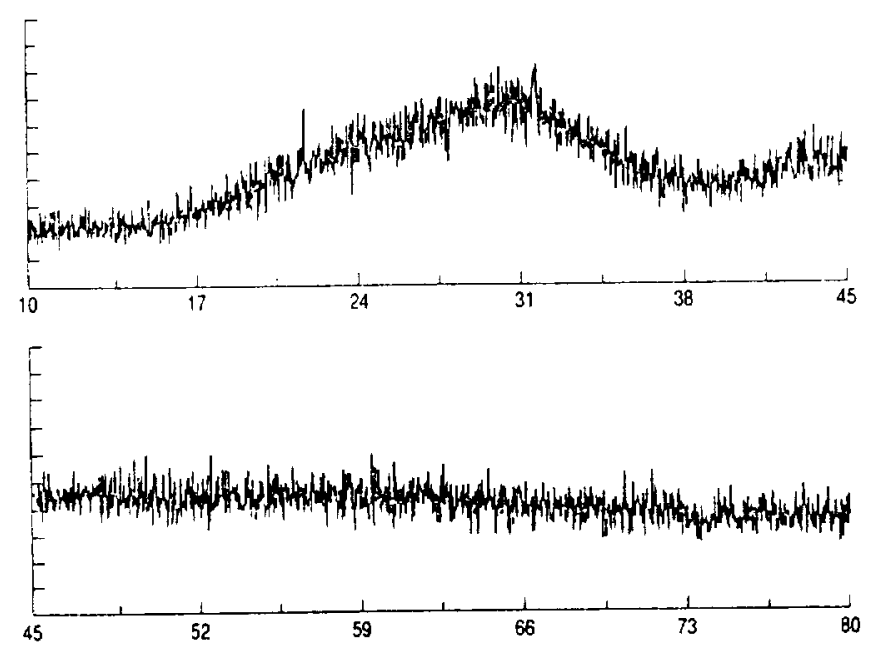

Fig. 5. X-ray pattern of as-melted $2 \mathrm{Y}_{2} \mathrm{O}_{3} \cdot 3 \mathrm{SiO}_{2}$. 


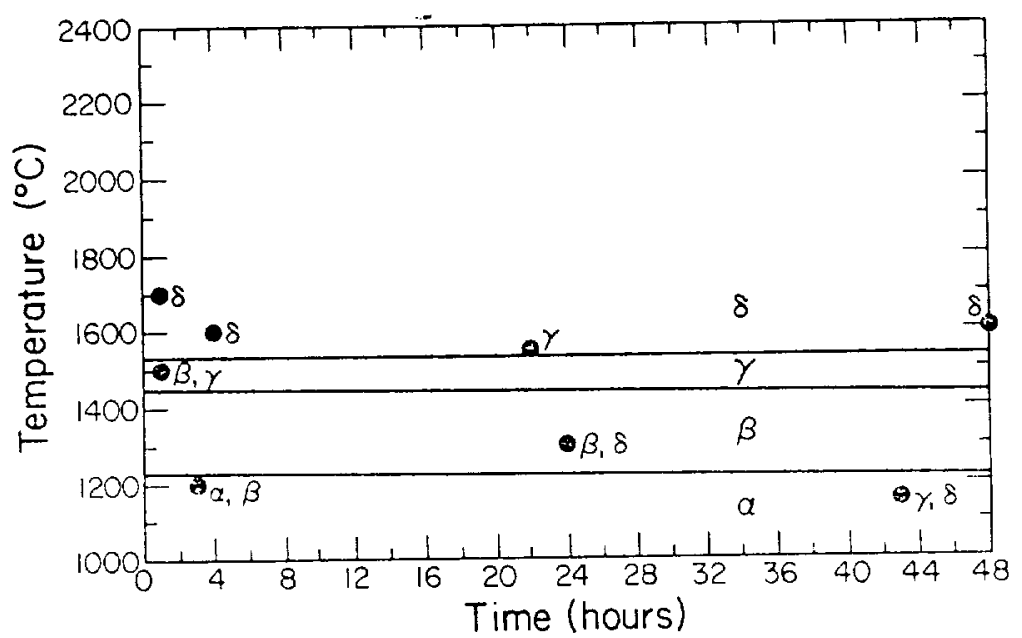

Fig. 6. Heat treatment studies of GSI.

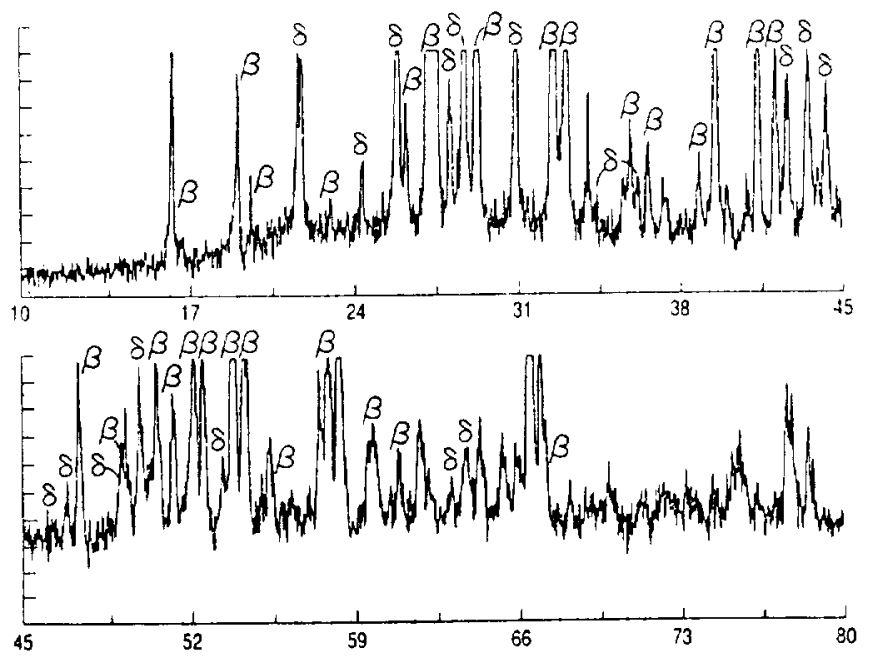

Fig. 7. X-ray pattern of GSI heat treated at $1300^{\circ} \mathrm{C}$ for $24 \mathrm{~h}$ with $\beta$ and $\delta-Y_{2} \mathrm{Si}_{2} \mathrm{O}_{7}$. 


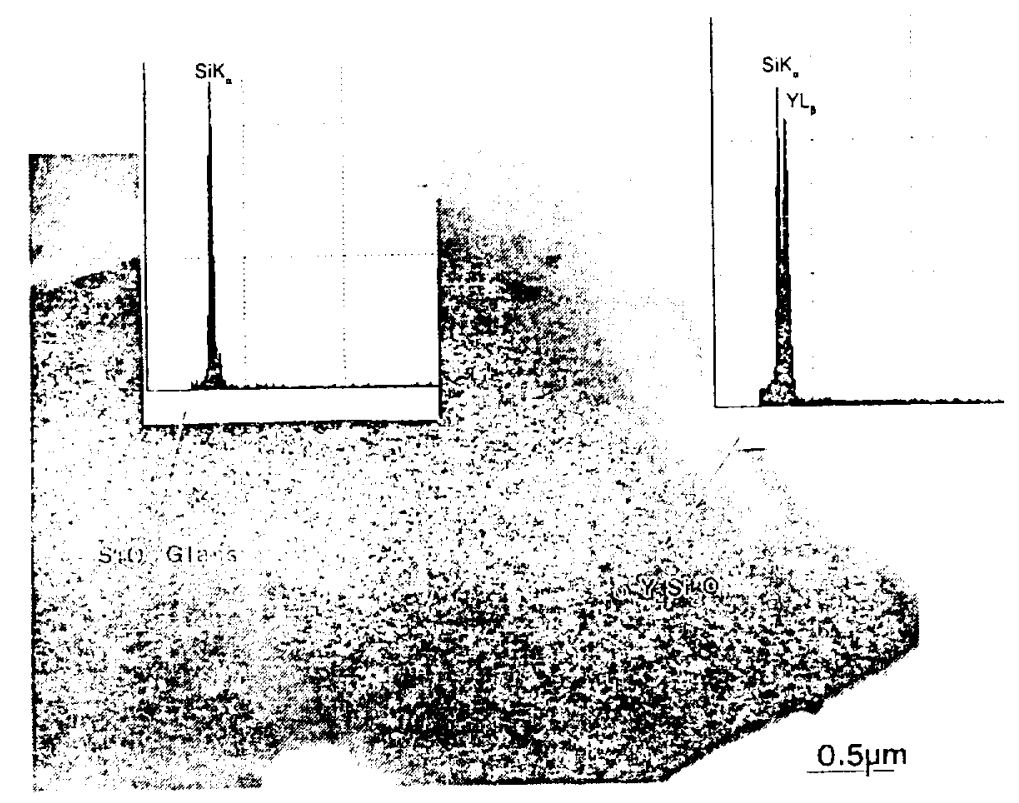

Fig. 8. TEM and AES of GSI heat treated at $1600^{\circ} \mathrm{C}$ for $4 \mathrm{~h}$.

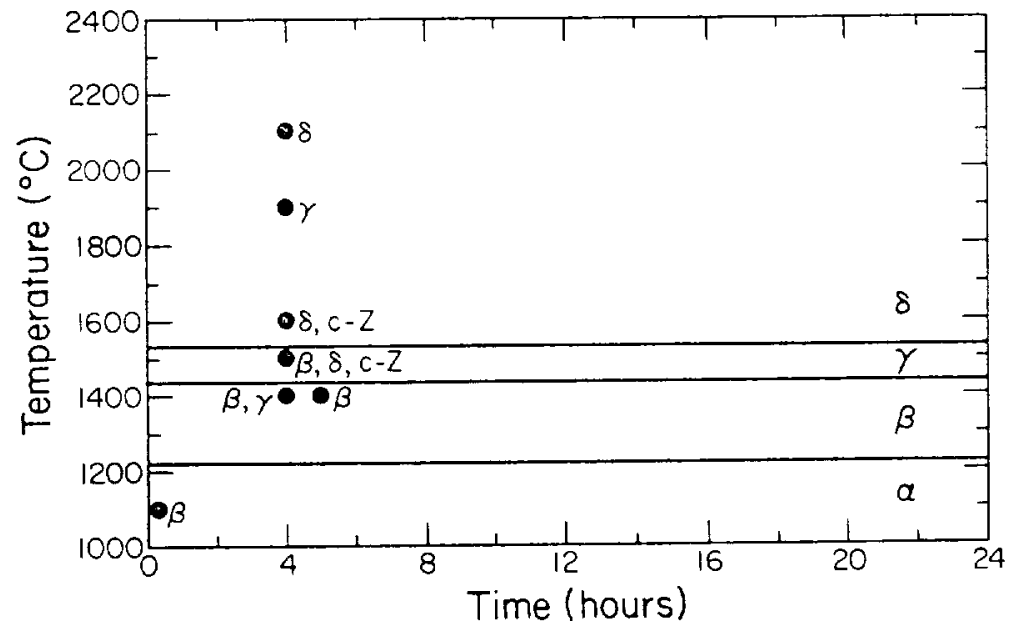

Fig. 9. Heat treatment studies of GSZ compositions. 


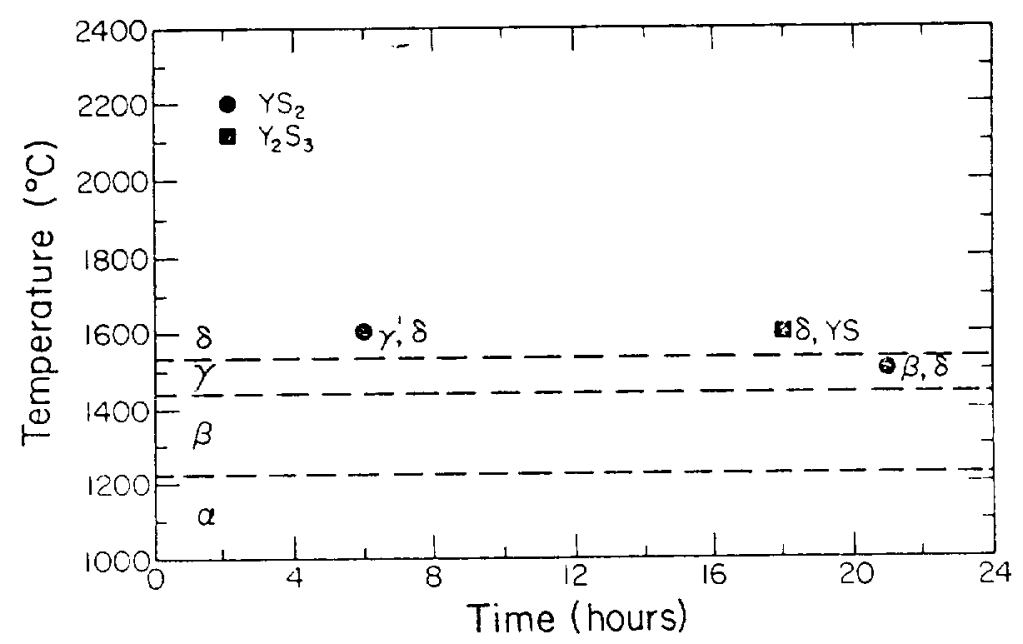

Fig. 10. Heat treatment studies of YS2 and Y2S3 compositions.

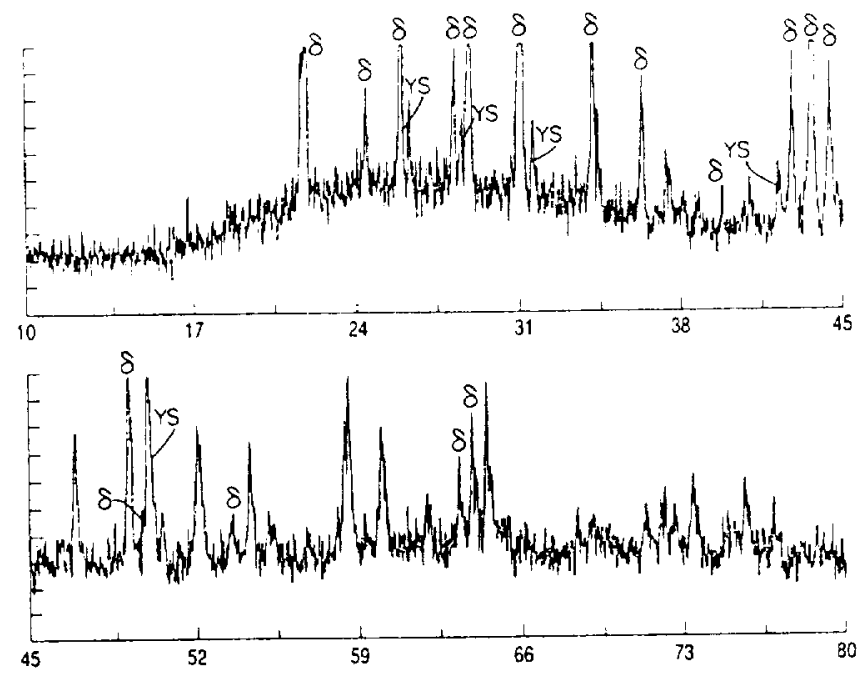

Fig. 11. X-ray pattern of $2 \mathrm{Y}_{2} \mathrm{O}_{3} \cdot 3 \mathrm{SiO}_{2}$ heat treated at $1600^{\circ} \mathrm{C}$ for $18 \mathrm{~h}$ with $\delta-\mathrm{Y}_{2} \mathrm{Si}_{2} \mathrm{O}_{7}$ and $\mathrm{Y}_{2} \mathrm{SiO}_{5}$. 


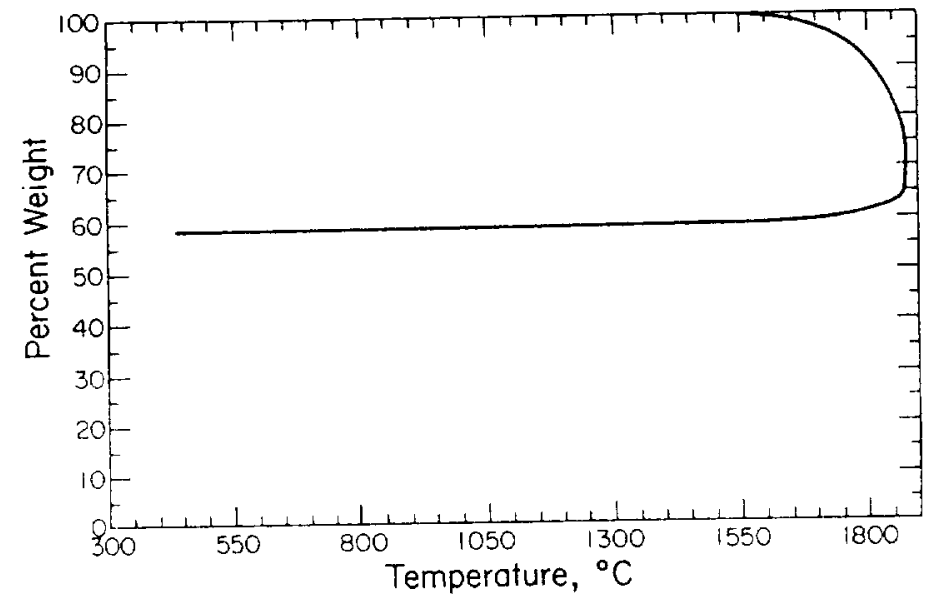

Fig. 12. TGA scan of GSZ5. 
Ceram. Eng. Sci. Proc., 9 [9-10] pp. 1355-1366 (1988)

\title{
Microstructural Evolution on Crystallizing the Glassy Phase in a 6 Weight \% $\mathrm{Y}_{2} \mathrm{O}_{3}-\mathrm{Si}_{3} \mathrm{~N}_{4}$ Ceramic
}

\author{
W. E. Lee, C. H. Drummond II, AND G. E. Hilmas \\ Department of Ceramic Engineering \\ The Ohio State University \\ Columbus, $\mathrm{OH} \quad 43210$
}

J. D. Kiser and W. A. Sanders

NASA Lewis Research Center

Cleveland, OH 44135

$X$-Ray diffraction and analytical electron microscopy have been used to study the crystallization of the grain-boundary glass in a $6 \mathrm{wt} \% \mathrm{Y}_{2} \mathrm{O}_{3}-S_{3} \mathrm{~N}_{1}$ ceramic. Upon crystallization, high densities of dislocations formed in the $\mathrm{Si}_{3} N_{4}$ grains and remained after $5 \mathrm{~h}$ at temperature. However, prolonged holds at the crystallization temperature effectively annealed out the dislocations. Other features present in the microstructure are characterized.

\section{Introduction}

Microstructural characterizations of liquid-phase sintered $\mathrm{Si}_{3} \mathrm{~N}_{4}$ have frequently been performed using scanning electron microscopy (SEM) to study fracture surfaces and identify failure sites. ${ }^{1-3}$ Lattice or structure imaging in the high resolution transmission electron microscope (TEM) has been carried out to detect small quantities of grain boundary glass. ${ }^{4-5}$ Other techniques such as energy dispersive spectroscopy (EDS) and energy loss spectroscopy (ELS) in the analytical electron microscope (AEM) have been used to quantitatively determine the chemical constituents of this glassy phase. ${ }^{6-7}$ Impurity phases in hot-pressed $\mathrm{Si}_{3} \mathrm{~N}_{4}$ were carefully analyzed by Lou et al. ${ }^{8}$ Only recently, however, have microstructural studies been extended to examine the evolution of the microstructure with time and temperature upon crystallizing the glass. Bonnell et al. ${ }^{9-10}$ examined crystallization of cordierite $\left(\mathrm{Mg}_{2} \mathrm{Al}_{4} \mathrm{Si}_{3} \mathrm{O}_{18}\right)$ and garnet $\left(\mathrm{Y}_{3} \mathrm{Al}_{5} \mathrm{O}_{12}\right)$ from $\mathrm{MgO}$ - and $\mathrm{Y}_{2} \mathrm{O}_{3}$-containing SiAlONs respectively. In the present work SEM, AEM, and optical microscopy have been utilized to examine the microstructures in NASA-6Y $\left(6 \mathrm{wt} \% \mathrm{Y}_{2} \mathrm{O}_{3}\right)$ composition $\mathrm{Si}_{3} \mathrm{~N}_{1}$ in the assintered condition and after a crystallizing heat treatment in $\mathrm{N}_{2}$ at $1500^{\circ} \mathrm{C}$ for times from $5-20 \mathrm{~h}$. We report here the results of AEM analysis.

\section{Experimental}

\section{Materials and Sample Fabrication}

Details of the starting powders and processing are given in a previous publication " and are summarized in Table I. Two series of bars were examined: series A using GTE SN502 $\mathrm{Si}_{3} \mathrm{~N}_{4}$ powder and series $\mathrm{B}$ using KBI-AME $\mathrm{Si}_{3} \mathrm{~N}_{4}$ powder. Series A was sintered and crystallized in $25 \operatorname{atm} \mathrm{N}_{2}$; series $\mathrm{B}$ was sintered and crystallized in 50 atm $\mathrm{N}_{2}$. 


\section{Characterization}

$X$-ray diffraction (XRD) of the as-treated surface of the $3 \times 0.56 \times 0.28 \mathrm{~cm}$ bars was carried out using a Philips APD 3600 powder diffractometer. AEM was performed on a Philips $400 \mathrm{EM}$ with an Ortec $500 \mathrm{EDS}$ system. The Be window on the EDS X-ray detector precludes detection of any element lighter than $\mathrm{Na}$ so that, unfortunately, neither $\mathrm{N}$ nor $\mathrm{O}$ could be analyzed with this system. Standard ceramographic grinding and polishing techniques were employed finishing with $3 \mu \mathrm{m}$ diamond paste. Three-mm diameter TEM disks were ultrasonically cut from 1-mm thick slices of the bars, ground and polished to about $100 \mu \mathrm{m}$ thickness, dimpled to $20 \mu \mathrm{m}$ center thickness and ion milled to electron transparency using $5 \mathrm{kV}$ Ar ions. Analysis of X-ray and electron diffraction patterns was facilitated by reference 12 for $\mathrm{Si}_{3} \mathrm{~N}_{4}$ and 13 for $\mathrm{Y}_{2} \mathrm{Si}_{2} \mathrm{O}_{7}$.

Results

\section{$X$-ray Diffraction}

Results of XRD analyses are given in Table II. Series A bars contain detectable amounts of $\mathrm{Si}_{2} \mathrm{ON}_{2}$ in all cases, even in the as-sintered material. This occurred even though series $\mathrm{A}$ had a lower starting $\mathrm{SiO}_{2}$ content because of contamination during the long milling time $(300 \mathrm{~h})$, a higher $\mathrm{SiO}_{2}$ content in the starting $\mathrm{Si}_{3} \mathrm{~N}_{4}$ powder, and because of possible oxidation of $\mathrm{Si}_{3} \mathrm{~N}_{4}$ upon milling. $\beta-\mathrm{Si}_{3} \mathrm{~N}_{4}$ was the only other phase found in the as-sintered material but on crystallizing at $1500^{\circ} \mathrm{C}$ for $5-20$ hours, $\beta-Y_{2} \mathrm{Si}_{2} \mathrm{O}$, peaks were also revealed.

As-sintered series B material was additionally subjected to a bend test in air at $1370^{\circ} \mathrm{C}$ before characterization which led to the formation of $\mathrm{Y}$ $\mathrm{Y}_{2} \mathrm{Si}_{2} \mathrm{O}_{7}{ }^{*}$ crystals from the glass. After crystallizing treatments of 5 and 10 $h$ at $1500^{\circ} \mathrm{C}$, as in the series A material, only $\beta-\mathrm{Y}_{2} \mathrm{Si}_{2} \mathrm{O}$, was formed. However, after $20 \mathrm{~h}$ at $1500^{\circ} \mathrm{C}$, only peaks attributable to a $\alpha-\mathrm{Y}_{2} \mathrm{Si}_{2} \mathrm{O}$, were detected.

\section{General Microstructure}

The same general trends in the microstructural features observed in the TEM were seen for both series $A$ and series $B$ material. The main difference was that greater amounts of $\mathrm{Si}_{2} \mathrm{ON}_{2}$ were apparent in series $\mathrm{A}$ (detected by $\mathrm{XRD}$ ) than in series $\mathrm{B}$ samples (not detected by $\mathrm{XRD}$ ). However, $\mathrm{Si}_{2} \mathrm{ON}_{2}$ was frequently detected in the TEM when examining series $B$ material even though the amount present must have been below the limits of detectability of the XRD unit (about 5 vol\%).

As-sintered $6 Y-S i_{3} N_{4}:$ Figure 1 is a bright-field TEM image of a typical area of the microstructure of $6 \mathrm{Y}$ material before crystallization consisting of hexagonal $\beta-\mathrm{Si}_{3} \mathrm{~N}_{4}$ grains in a glassy matrix. The glass appears dark since it contains high atomic number $\mathrm{Y}$ which absorbs many of the electrons so that they do not contribute to the transmitted image. An EDS spectrum from the glass is also shown indicating the presence of $\mathrm{Y}$ and $\mathrm{Si}(\mathrm{O}$ and $\mathrm{N}$ are not detected with this system). Low densities of dislocations were observed in about $40 \%$ of the $\mathrm{Si}_{3} \mathrm{~N}_{4}$ grains examined (e.g. as arrowed in Figure 1). We intend to carry out ELS analysis of the as-sintered glass to determine the $\mathrm{N}$ content (if any) and $O$ content.

\footnotetext{
*There are five polymorphs of $\mathrm{Y}, \mathrm{Si}, \mathrm{O}$, as described in reference 22.
} 
After $5 \mathrm{~h}$ at $1500^{\circ} \mathrm{C}$ : All specimens prepared for TEM after this heat treatment were observed to crack on ion milling, a first indication that they were under a large stress. $\beta-\mathrm{Y}_{2} \mathrm{Si}_{2} \mathrm{O}$, crystals were seen at the grain boundaries shown as the dark phase in the bright field image of Fig. 2. The EDS spectrum for this phase shows that the $\mathrm{Y} \mathrm{L}_{\alpha}, \mathrm{L}_{\beta}$ - doublet peak is just smaller than the $\mathrm{Si}$ $\mathrm{K}_{a}, \mathrm{~K}_{\mathrm{a}}$ doublet peak. Note, however that spectra from this phase must be collected from the edge of the sample away from $\mathrm{Si}_{3} \mathrm{~N}_{4}$ grains to stop $\mathrm{X}$-rays generated from the $\mathrm{Si}$ in the $\mathrm{Si}_{3} \mathrm{~N}_{4}$ from reaching the detector, otherwise anomalously high Si peaks result. Figure 3 is a dark-field image where a single reflection from the $\beta-Y_{2} \mathrm{Si}_{2} \mathrm{O}$, has illuminated crystalline regions at the same orientation extending over large areas of the microstructure. It appears that most of the material that was glass before this heat treatment has crystallized at this stage although high-resolution lattice imaging is needed to confirm this.

Figure 4 is a low magnification image of the microstructure. Note the large number of strain fields in the $\mathrm{Si}_{3} \mathrm{~N}_{4}$ grains due to the presence of extensive dislocation networks. Dislocations were observed in about $85 \%$ of the grains examined and at much higher densities than in the as-sintered material. Determining the presence of dislocations in a particular grain requires extensive tilting to bring the grain to an orientation at which the dislocation is visible. Work is in progress to quantify the dislocation densities and to analyze their habit planes and Burgers vectors. Figure 5 is a weak-beam dark-field image of some of these dislocations using $g=0002$. This technique is frequently used when examining high densities of dislocations in ceramics since it images only the core of the dislocation and removes the problem of overlapping strain fields seen in conventional bright- or dark-field images.

After $10-20 \mathrm{~h}$ at $1500^{\circ} \mathrm{C}$ : Similar microstructures were observed in these samples as after $5 \mathrm{~h}$ at $1500^{\circ} \mathrm{C}$ except that the dislocation densities were reduced almost to the level of the as-sintered material (Fig. 6). Specimens did not crack on ion milling.

\section{Other Observations}

Several other features were observed in the microstructures using TEM and are worthy of note.

$\alpha-S_{3} N_{4}$ : Rounded grains of $\alpha-\mathrm{Si}_{3} \mathrm{~N}_{4}$ were occasionally observed in all specimens (e.g. arrowed in Fig. 6). Careful analysis of diffraction patterns was required to distinguish these grains from the hexagonally-shaped $\beta-\mathrm{Si}_{3} \mathrm{~N}_{4}$ grains. The $\alpha$ grains presumably are particles from the original starting powder which did not dissolve during sintering. Observing large numbers of these grains would indicate the need for longer sintering times or higher temperatures although the amounts detected here were small and below the level of detectability of the XRD unit for series B.

Precipitates in the $\beta-\mathrm{Si}_{3} N_{4}$ Grains: Occasionally, small (about $150 \mathrm{~nm}$ diameter) crystals were observed inside $\beta-\mathrm{Si}_{3} \mathrm{~N}_{4}$ grains. EDS analysis of the crystal indicated the presence of silicon, and electron diffraction patterns identified them as being $\beta-\mathrm{SiC}$, an impurity phase also observed by Lou et al. ${ }^{8}$ in their TEM study of hot-pressing $\mathrm{Si}_{3} \mathrm{~N}_{4}$. The crystals are faulted on (111) giving rise to the streaks in the microdiffraction pattern of Fig. 7. The starting powders used in the production of these samples are known to contain about $0.1 \mathrm{wt} \% \mathrm{C}^{\prime \prime}$ which apparently forms into $\mathrm{SiC}$ during the solution- 
precipitation sintering process. This observation has practical significance since it is known that carbon impurities reduce the oxidation resistance of $\mathrm{Y}_{2} \mathrm{O}_{3}-\mathrm{Si}_{3} \mathrm{~N}_{4}$ ceramics. ${ }^{14}$

$\mathrm{Si}_{2} \mathrm{ON}_{2}$ Crystals: Detecting the presence of silicon oxynitride was relatively straightforward in the TEM due to the presence of stacking faults (and occasionally twins) on (100) planes as observed previously by Lewis et al. ${ }^{15}$ However, two distinct morphologies of $\mathrm{Si}_{2} \mathrm{ON}_{2}$ were seen. Commonly, the $\mathrm{Si}_{2} \mathrm{ON}_{2}$ crystals occurred as long, orthorhombic-shaped grains with the stacking faults running along the long (100) axis of the crystal (Fig. 8). The presence of streaks in the diffraction patterns was a strong indication that the grain was $\mathrm{Si}_{2} \mathrm{ON}_{2}$. Less common was the appearance of some $\mathrm{Si}_{2} \mathrm{OH}_{2}$ crystallized with the same morphology as the $\mathrm{Y}_{2} \mathrm{Si}_{2} \mathrm{O}$, phase, i.e. crystallizing around the $\mathrm{Si}_{3} \mathrm{~N}_{4}$ grains (Fig. 9). This morphology was less inclined to contain stacking faults and so was more difficult to detect. EDS was required to distinguish this from of $\mathrm{Si}_{2} \mathrm{ON}_{2}$ from $\mathrm{Y}_{2} \mathrm{Si}_{2} \mathrm{O}_{1}$, as was careful analysis of diffraction patterns. In both morphologies, small crystals were seen inside the grains similar to the observation of $\beta-\mathrm{SiC}$ crystals in $\beta-\mathrm{Si}_{3} \mathrm{~N}_{4}$ noted above. However, preliminary analysis suggests that these crystals are simply $\mathrm{Si}_{2} \mathrm{ON}_{2}$ microcrystals at a different orientation to the parent grain and not a second phase.

\section{Discussion}

Crystallization of the grain-boundary glass to increase the refractoriness of $\mathrm{Si}_{3} \mathrm{~N}_{4}$ ceramics has been intensively studied since the work of Tsuge et al. ${ }^{16}$ in the $\mathrm{Y}_{2} \mathrm{O}_{3}-\mathrm{Si}_{3} \mathrm{~N}_{4}$ system. The NASA $6 \mathrm{Y}$ composition is chosen to lie in the oxidation-resistant $\mathrm{Si}_{2} \mathrm{ON}_{2}-\mathrm{Si}_{3} \mathrm{~N}_{4}-\mathrm{Y}_{2} \mathrm{Si}_{2} \mathrm{O}$, triangle of the $\mathrm{Si}_{3} \mathrm{~N}_{4}-\mathrm{SiO}_{2}-\mathrm{Y}_{2} \mathrm{O}_{3}$ phase diagram and the microstructural results presented here confirm the presence of these phases along with the occasional impurity grains such as $\beta-\mathrm{SiC}$ (Fig. 7). The increase in dislocation density in the $\mathrm{Si}_{3} \mathrm{~N}_{4}$ grains upon formation of $\mathrm{Y}_{2} \mathrm{Si}_{2} \mathrm{O}$, after $5 \mathrm{~h}$ at $1500^{\circ} \mathrm{C}$ was unexpected. Cracking of TEM specimens on ion milling is a clear indication that this material's nechanical properties are adversely affected by this strain. The reduction in dislocation densities with prolonged heating at $1500^{\circ} \mathrm{C}$, however, suggests that the dislocations can be annealed out without difficulty.

The reason for the appearance of dislocations is likely to be associated with a volume difference between the yttrium silicate glass and the first $\mathrm{Y}_{2} \mathrm{Si}_{2} \mathrm{O}$, crystals formed or volume differences between some of the $\mathrm{Y}_{2} \mathrm{Si}_{2} \mathrm{O}_{7}$ polymorphs. Alternatively, differences in thermal expansion between the various phases may lead to stress in the system. Densities of the polymorphic forms of $\mathrm{Y}_{2} \mathrm{Si}_{2} \mathrm{O}_{7}$ are available but the density of the glass is not. Experiments are currently being performed to determine the density of glasses with this composition. A volume change (increase or decrease) will impose a strain on the $\mathrm{Si}_{3} \mathrm{~N}_{4}$ grains, deforming them and causing dislocations to form. The dislocation microstructures formed in the crystallized material are typical of deformation-induced microstructures seen in other ceramics. ${ }^{17}$ According to Liddell and Thompson, ${ }^{13} \alpha-Y_{2} \mathrm{Si}_{2} \mathrm{O}_{7}$ transforms to the $\beta$ form at $1225^{\circ} \mathrm{C}$ which should transform to $y-Y_{2} \mathrm{Si}_{2} \mathrm{O}$, at $1445^{\circ} \mathrm{C}$. Since crystallization was carried out at $1500^{\circ} \mathrm{C}$ and $\gamma-\mathrm{Y}_{2} \mathrm{Si}_{2} \mathrm{O}_{7}$ was never observed, the $\gamma$ to $\beta$ transformation must be rapid. Since the $\beta$ to $\alpha$ transformation did not occur when cooling below the $\beta$ phase field it, however, must be sluggish. The volume change associated with the only polymorphic transformation to occur $(\gamma$ to $\beta)$ is small $(0.2 \%)$ and so the most likely cause(s) of dislocation formation is (are) a volume change 
on crystallization from the glass or differences in thermal expansion behavior. However, as stated above, since the dislocations can be annealed out at the crystallization temperature, their formation need not affect the mechanical properties.

Hayashi et al. 18 note a decrease in flexural strength after crystallization in pressureless-sintered $\mathrm{Al}_{2} \mathrm{O}_{3}-\mathrm{Y}_{2} \mathrm{O}_{3}-\mathrm{Si}_{3} \mathrm{~N}_{4}$ ceramics which they attribute to a change in specific volume of grain boundary phases and difference of thermal expansion coefficients between $\mathrm{Si}_{3} \mathrm{~N}_{4}$ and the crystallized phases.

While a thorough analysis of the dislocations observed in both as-sintered (presumably simple growth defects) and crystallized $\mathrm{Si}_{3} \mathrm{~N}_{4}$ is not yet complete, a few words concerning previous studies of dislocations in this material seem in order. Studies of dislocations in $\mathrm{Si}_{3} \mathrm{~N}_{4}$ are sparse. Evens and Sharp ${ }^{19}$ and Butler ${ }^{20}$ studied dislocations in hot-pressed and reaction-sintered materials. In both forms most of the dislocations had a $\langle 0001\rangle$-type Burgers vector, $b$, although other types of dislocation were present. Consideration of the strain energy associated with various types of dislocation in $\mathrm{Si}_{3} \mathrm{~N}_{4}{ }^{19}$ indicated that $\langle 0001\rangle$ was the most stable Burgers vector whereas an analysis of dislocation mobility using the Perierls model suggested they would also be the most mobile with $\{10 \overline{1} 0\}$ as the primary slip plane.

The observation that $\mathrm{Y}_{2} \mathrm{Si}_{2} \mathrm{O}_{7}$ crystallizes at a single orientation (i.e. as a single crystal) over large distances in the microstructure (Fig. 3 ) is interesting. Similar behavior was seen by Bonnell et al. ${ }^{10}$ in garnet $\left(\mathrm{Y}_{3} \mathrm{Al}_{3} \mathrm{O}_{12}\right)$ crystallized in SiAION grain boundaries but not when cordierite $\left(\mathrm{Mg}_{2} \mathrm{Al}_{4} \mathrm{Si}_{5} \mathrm{O}_{18}\right)$ was crystallized. It is suspected that this behavior is a function of the ease or difficulty of nucleating the second phase; the easier nucleation is the less chance of crystals growing around the $\mathrm{Si}_{3} \mathrm{~N}_{4}$ grains. Since crystallization of $\mathrm{Y}_{2} \mathrm{Si}_{2} \mathrm{Y}_{7}$ is observed around several $\mathrm{Si}_{3} \mathrm{~N}_{4}$ grains. Since crystallization of $\mathrm{Y}_{2} \mathrm{Si}_{2} \mathrm{O}$, is observed around several $\mathrm{Si}_{3} \mathrm{~N}_{4}$ grains, it seems likely that complete crystallization of all the glass in that area had occurred even though the very thin intergranular regions were not illuminated in dark-field images. High-resolution TEM is planned to determine the extent of crystallization in this material. The crystallization morphologies of the $\mathrm{Y}_{2} \mathrm{Si}_{2} \mathrm{O}_{2}$ polymorphs formed from bulk glass are currently being studied in several complex systems. ${ }^{21-22}$

\section{References}

W A Sintered Si,Na With Rare-Earth-Oxide Additions," Ceram. Bull., 64 [2] 304-309 (1985).

${ }^{2}$ R. K. Govila, "Uniaxial Tensile and Flexural Stress Rupture Strength of Hot-Pressed Si,N.," J. Am. Ceram. Soc., 65 [1] 15-21 (1982).

J W Richerson and J M. Wimmer, "Properties of Isostatically Hot-Pressed Silicon Nitride,"J. Am. Ceram. Soc., 66 C-173-76 (1983).

"D. R. Clarke "Direct Observation of Lattice Planes at Grain Boundaries in Silicon Nitride," pp. 433-40 in Nitrogen Ceramics Edited by F. L. Riley (Noordhoff, The Netherlands 1977). 'O. L. Krivanek, T. M. Shaw, and G. Thomas, "Imaging of Thin Intergranular Phases by

High-Resolution Electron Microscopy," J. Appl. Phys, 50 [6] 4223-27 (1979). Silicon Nitride: I, Elemental Composition,"J. Am. Ceram. Soc., 64 [10] 601-7 (1981).

'S. A Bradley and K. R. Karasek, "Analysis of Grain Boundaries for Reaction-Bonded Silicon Nitride with Ytria Addition," J. Mats. Sci. Lett., 6 791-94 (1987).

"L X V J. Am Ceram. Soc., 61 [9-10] 392-96 (1978).

'D. A. Bonnell, M. Ruhle, and T.Y. Tien, "Redistribution of Aluminum Ions During Processing of Sialon Ceramics," J. Am. Ceram. Soc., 69 [8] 623-27 (1986).

10 phase in Silicon Nitride Ceramics," J. Am. Ceram. Soc., 70 [7] 460-65 (1987). 
"W. A. Sanders and G. Y. Baaklini, "Correlation of Processing and Sintering Variables With the Strength and Radiography of Silicon Nitride," Cer. Eng. and Sci. Proc., 7 [7-8] 839-59 (1986).

${ }_{12}^{2}$ J. V. Sharp, A. G. Evans, and B. Hudson, "Electron Diffraction Data for Silicon Nitride," UKAEA Harwell Report AERE-R7319 (1972).

"K. Liddell and D. P. Thompson, "X-ray Diffraction Data for Yttrium Silicates," Br. Ceram. Trans. J., 85 17-22 (1986).

"H. Knoch and G. E. Gazza, "Effect of Carbon Impurity on the Thermal Degradation of an $\mathrm{Si}_{1} \mathrm{~N}-\mathrm{Y}, \mathrm{O}$, Ceramic," J. Am. Ceram. Soc., 62 [11-12] 634-35 (1979).

"M. H. Lewis, C. J. Reed, and N. D. Butler, "Pressureless-Sintered Ceramics Based on the Compound $\mathrm{Si}_{2} \mathrm{~N}_{2} \mathrm{O}$," Mats. Sci. and Eng., 71 87-94 (1985).

is A Tsuge K. Nishida, and M Komatsu "Effect of Crystallizing the Grain-Boundary Glass Phase on the High-Temperature Strength of Hot-Pressed $\mathrm{Si}_{3} \mathrm{~N}_{4}$ Containing $\mathrm{Y}_{2} \mathrm{O}_{1}, " J$. Am. Ceram. Soc., $58[7-8]$ 323-26 (1975).

"iT E Mitchell, "Application of Transmission Electron Microscopy to the Study of Deformation in Ceramic Oxides," J. Am. Ceram. Soc., 62 [5-6] 254-67 (1979).

"T. Hayashi, H. Munakata, H. Suzuki, and H. Saito, "Pressureless Sintering of Si, N, with $\mathrm{Y}_{3} \mathrm{O}$, and $\mathrm{Al}_{2} \mathrm{O}_{3}, " J$. Wat. Sci., 21 3501-3508 (1986).

"A. G. Evans and J.V. Sharp. "Microstructural Studies in Silicon Nitride," J. Mats. Sci. $61292-1302$ (1971).

"E. Butler, "Observations of Dislocations in $\beta$-Silicon Nitride," Phil. Mag., 24 829-34 (1971).

"T R. Dinger, R. S. Rai, and G. Thomas, "Crystallization Behavior of a Glass in the Y,O,-SiO,-AIN System," J. Am. Ceram. Soc., 71 [4] 236-44 (1988).

${ }^{21} \mathrm{C}$. H. Drummond III, W. E. Lee, W. A. Sanders, and J. D. Kiser, "Crystallization and Characterization of $\mathrm{Y}_{2} \mathrm{O}_{1}-\mathrm{SiO}_{2}$ Glasses," these proceedings.

Table I. Powders and Processing Conditions

\begin{tabular}{|c|c|c|c|c|c|c|c|}
\hline & \multirow[b]{2}{*}{ Powder } & \multirow[b]{2}{*}{$\begin{array}{c}\text { Mill charge } \\
(\text { wt } \%)\end{array}$} & \multirow[b]{2}{*}{$\begin{array}{l}\text { Mill time } \\
(\mathrm{h})\end{array}$} & \multicolumn{3}{|c|}{ Sintering } & \multirow{2}{*}{$\begin{array}{l}\text { Crystallizing } \\
\mathrm{N}_{2} \text { pressure } \\
\text { (atm) }\end{array}$} \\
\hline & & & & $\begin{array}{l}\text { Temp. } \\
\left({ }^{\circ} \mathrm{C}\right)\end{array}$ & $\begin{array}{c}\text { Time } \\
(h)\end{array}$ & $\begin{array}{c}N_{2} \text { pressure } \\
(\mathrm{atm})\end{array}$ & \\
\hline Series A & $\begin{array}{l}\mathrm{Si}_{3} \mathrm{~N}_{4}{ }^{*} \\
\mathrm{SiO}_{2}^{\dagger} \\
\mathrm{Y}_{2} \mathrm{O}_{3}{ }^{\ddagger}\end{array}$ & $\begin{array}{l}95.4 \\
0 \\
4.6\end{array}$ & 300 & 2140 & 1 & 25 & 25 \\
\hline Series B & $\begin{array}{l}\mathrm{Si}_{3} \mathrm{~N}_{4}{ }^{\S} \\
\mathrm{SiO}_{2} \\
\mathrm{Y}_{2} \mathrm{O}_{3}\end{array}$ & $\begin{array}{r}90.0 \\
3.6 \\
6.4\end{array}$ & 100 & 2140 & 4 & 50 & 50 \\
\hline
\end{tabular}

*GTE SN $50299.95 \%$ purity, $71.5 \%$ a, $1.5 \% \quad \beta, 27 \%$ amorphous.

Apache Chemicals Inc., Code 6846, $99.99 \%$.

iMolycorp. $5600,99.9 \%$.

IKBI-AME high purity, $99.5 \%, 83.7 \% \alpha, 15.7 \% \beta, 0.6 \% \mathrm{Si}$. 
Table II. XRD Results

\begin{tabular}{|c|c|c|}
\hline \multirow{2}{*}{$\begin{array}{l}\text { Crystallizing } \\
\text { Time } \\
\text { (h) }\end{array}$} & \multicolumn{2}{|c|}{ Phases Present } \\
\hline & Series A & Series B \\
\hline 0 & $\beta-\mathrm{Si}_{3} \mathrm{~N}_{4}, \mathrm{Si}_{2} \mathrm{~N}_{2} \mathrm{O}^{*}$ & $\beta-\mathrm{Si}_{3} \mathrm{~N}_{4}, \mathrm{Y}-\mathrm{Y}_{2} \mathrm{Si}_{2} \mathrm{O},{ }^{\dagger}$ \\
\hline 5 & $\begin{array}{l}\beta-\mathrm{Si}_{3} \mathrm{~N}_{4}, \mathrm{Si}_{2} \mathrm{~N}_{2} \mathrm{O} \\
\beta-\mathrm{Y}_{2} \mathrm{Si}_{2} \mathrm{O},\end{array}$ & $\beta-\mathrm{Si}_{3} \mathrm{~N}_{4}, \beta-\mathrm{Y}_{2} \mathrm{Si}_{2} \mathrm{O}_{7}$ \\
\hline 10 & $\begin{array}{l}\beta-\mathrm{Si}_{3} \mathrm{~N}_{4}, \mathrm{Si}_{2} \mathrm{~N}_{2} \mathrm{O}, \\
\beta-\mathrm{Y}_{2} \mathrm{Si}_{2} \mathrm{O},\end{array}$ & $\mathrm{B}-\mathrm{Si}_{3} \mathrm{~N}_{1}, \beta-\mathrm{Y}_{2} \mathrm{Si}_{2} \mathrm{O}$ \\
\hline 15 & $\begin{array}{l}\beta-\mathrm{Si}_{3} \mathrm{~N}_{4}, \mathrm{Si}_{2} \mathrm{~N}_{2} \mathrm{O}, \\
\beta-\mathrm{Y}_{2} \mathrm{Si}_{2} \mathrm{O},\end{array}$ & No data \\
\hline 20 & $\begin{array}{l}\beta-\mathrm{Si}_{3} \mathrm{~N}_{4}, \mathrm{Si}_{2} \mathrm{~N}_{2} \mathrm{O}, \\
\beta-\mathrm{Y}_{2} \mathrm{Si}_{2} \mathrm{O}\end{array}$ & $\beta-\mathrm{Si}_{3} \mathrm{~N}_{4}, \alpha-\mathrm{Y}_{2} \mathrm{Si}_{2} \mathrm{O}_{7}^{\ddagger}$ \\
\hline
\end{tabular}

*High $\mathrm{SiO}_{2}$ content due to contamination from milling media, high $\mathrm{SiO}_{2}$ in $\mathrm{Si}_{1} \mathrm{~N}_{4}$ powder, and possible oxidation on milling.

TFormed during bend test in air at $1370^{\circ} \mathrm{C}$.

IIdentified from 2 peaks only.

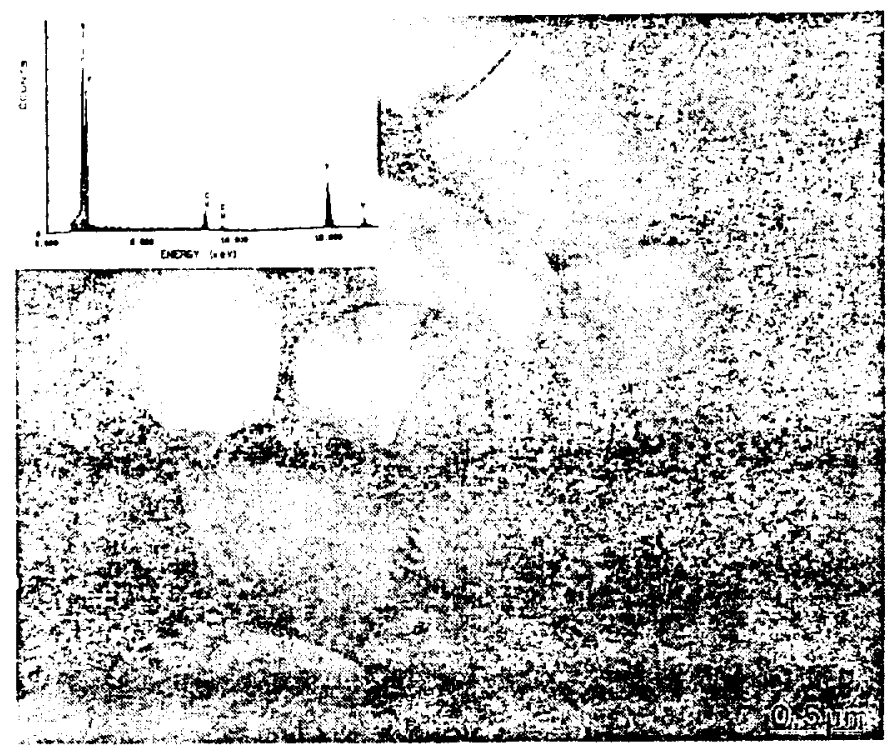

Fig. 1. Bright-field TEM image of as-sintered $\mathrm{Si}_{3} \mathrm{~N}_{4}$. Inset is an EDS spectrum from the glassy phase. 


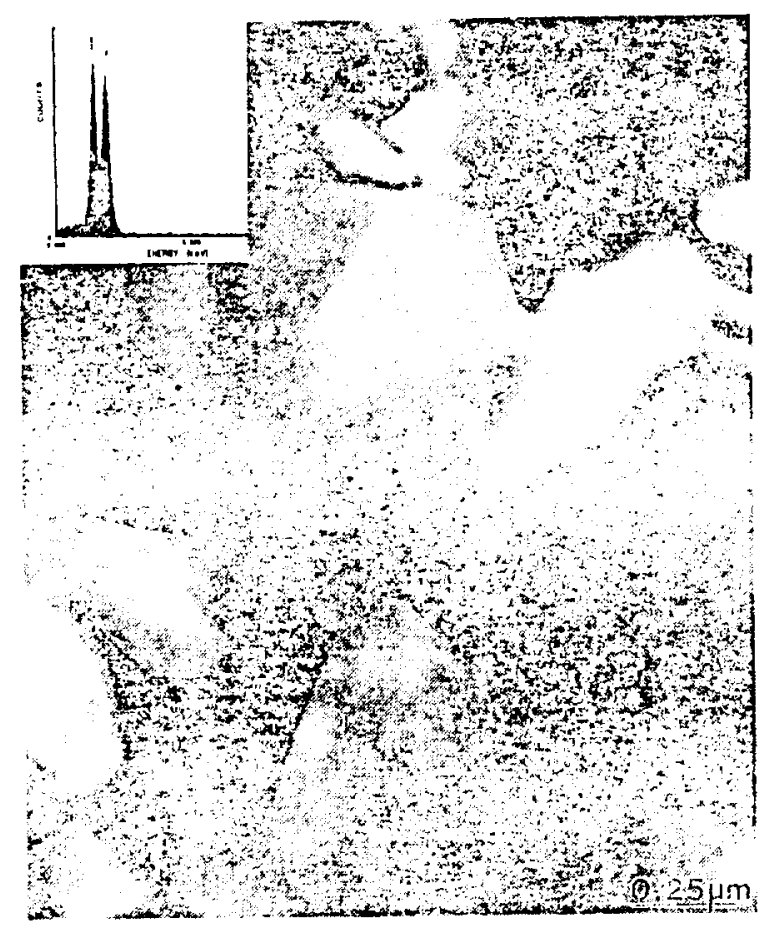

Fig. 2. Bright-field TEM image of $\mathrm{Si}_{3} \mathrm{~N}_{4}$ after crystallization for $5 \mathrm{~h}$ at $1500^{\circ} \mathrm{C}$ Inset is an EDS spectrum from $\mathrm{Y}_{2} \mathrm{Si}_{2} \mathrm{O}_{7}$.

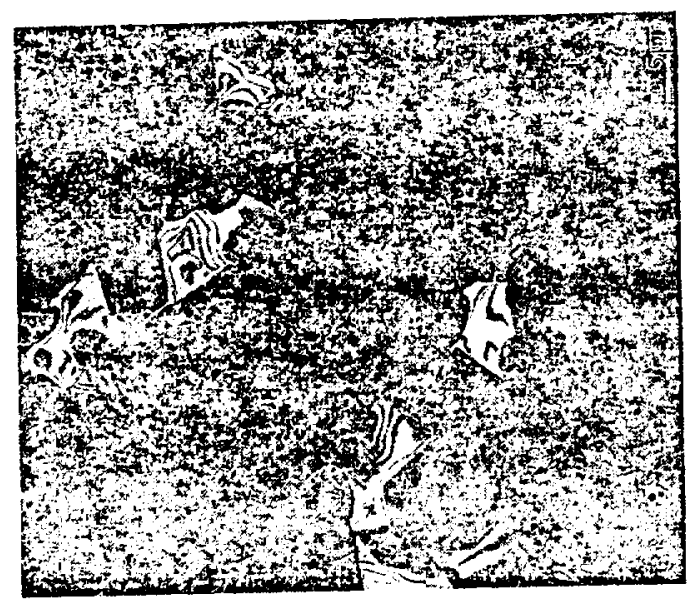

Fig. 3. Dark-field TEM image of $\beta-Y_{2} \mathrm{Si}_{2} \mathrm{O}_{7}$ at a single orientation 


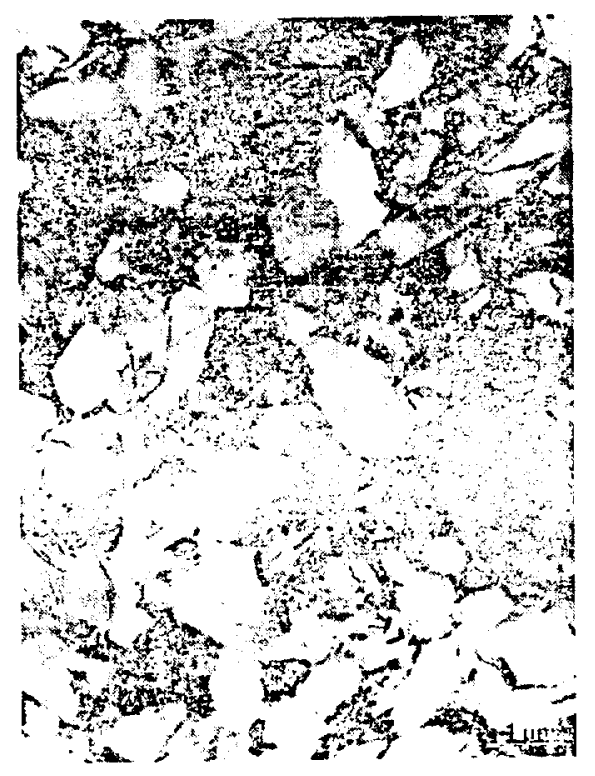

Fig. 4. Bright field TEM image showing large amounts of strain in $\mathrm{Si}_{3} \mathrm{~N}_{4}$ grains after $5 \mathrm{~h}$ at $1500^{\circ} \mathrm{C}$.

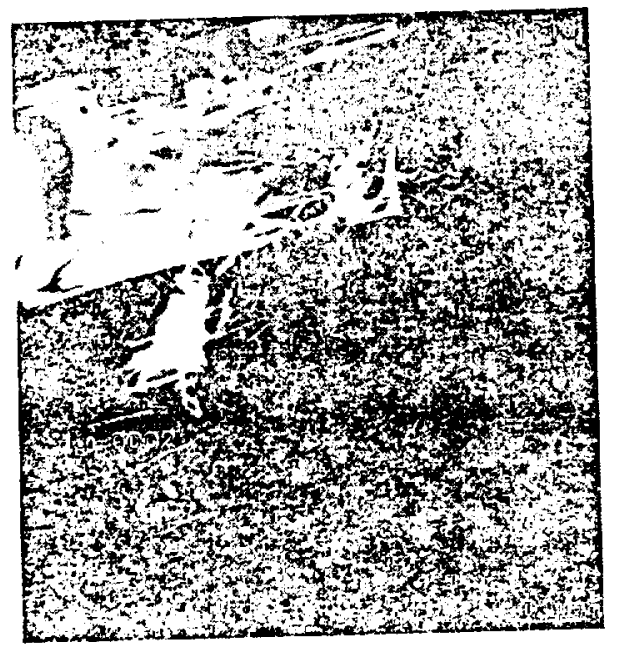

Fig. 5. Weak-beam dark-field TEM image of a dislocation network in a $\mathrm{Si}_{3} \mathrm{~N}_{4}$ grain. 


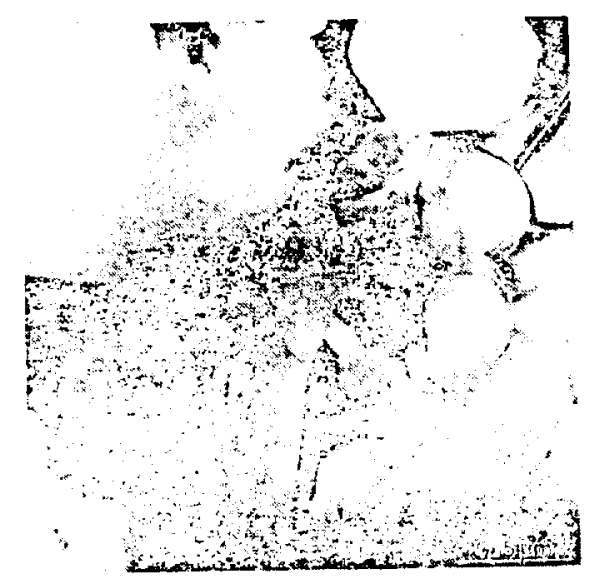

Fig. 6. Bright-field TEM image showing reduced dislocation density after 20 $h$ at $1500^{\circ} \mathrm{C}$. Arrows indicate $\alpha-\mathrm{Si}_{3} \mathrm{~N}_{4}$ grains.

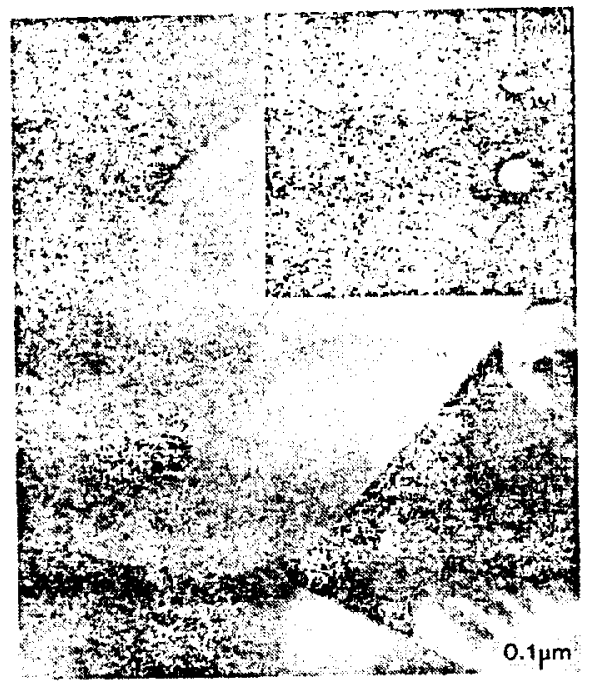

Fig. 7. $\quad \beta-\mathrm{SiC}$ precipitate in $\mathrm{Si}_{3} \mathrm{~N}_{4}$ grain. Inset is a microdiffraction pattern from $\beta$-SiC grain with streaking along (111). 


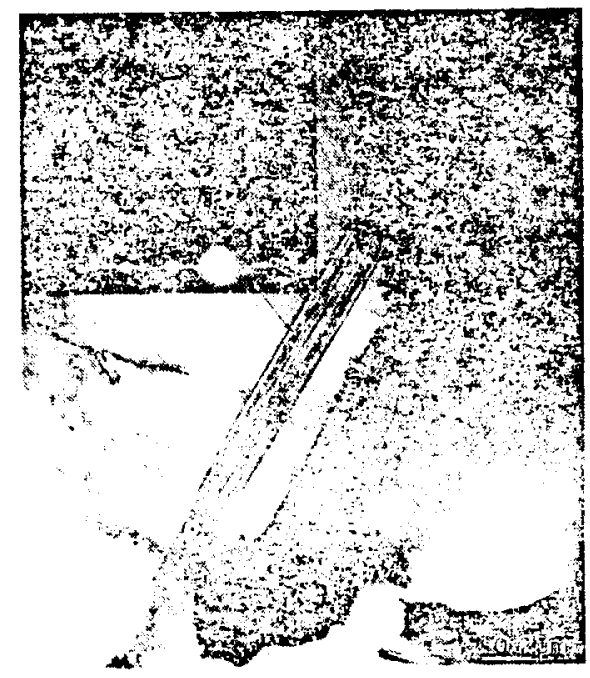

Fig. 8. Orthorhombic $\mathrm{Si}_{2} \mathrm{ON}_{2}$ grain with stacking faults on (100). Inset difraction pattern showing streaks on (100).

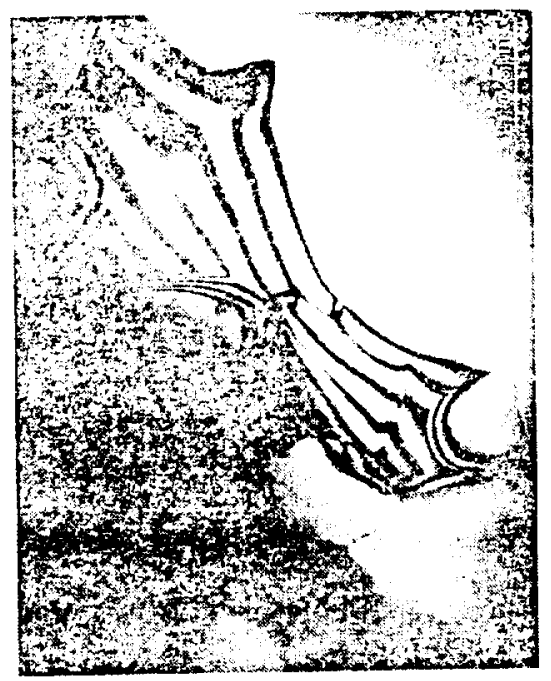

Fig. 9. $\mathrm{Si}_{2} \mathrm{ON}_{2}$ grain crystallizing around $\mathrm{Si}_{3} \mathrm{~N}_{4}$ grains. 